\title{
Breve comentario sobre el estudio de los conceptos de emoción
}

\section{Brief comments on the study of emotion concepts}

\author{
James A. Russell (1)
}

Desde, por lo menos, los antiguos filósofos griegos, los intelectuales han estudiado el lenguaje cotidiano por lo que revela respecto a todo lo que denota. Tal estudio asume generalmente que los términos generales de cualquier lenguaje denotan clases de objetos definidas adecuadamente; que la mayor parte de las palabras tendrían equivalentes en todos los lenguajes; que los conceptos universales expresados por estas palabras fueron definidos por medio de características necesarias y suficientes, y que cualquiera que pueda usar una palabra adecuadamente conoce, al menos implícitamente, esos rasgos (de ahí el método socrático para la extracción de ese conocimiento).

Los psicólogos de la emoción han presupuesto generalmente que las palabras del lenguaje cotidiano eran adecuadas para los fines del científico. Han supuesto además que palabras tales como emoción, enojo, miedo, etc., están adecuadamente definidas y relacionadas con objetos, ya que se supone que los nombres se refieren a cosas. Tales objetos serían universales y todo lo demás. Se hizo un esfuerzo importante pero casi totalmente olvidado por articular definiciones. Estos supuestos fueron aceptados sin reservas por la mayor parte de los autores. (Una excepción
At least since the ancient Greek philosophers, scholars have examined everyday language for what it reveals about everything it denotes. This examination generally presupposed that the general terms of any language denoted properly defined classes of things; that all languages would have mostly equivalent: words; that the universal concepts expressed by these words were defined by necessary and sufficient features; and that everyone who could use a word properly knew, at least implicitly, those features (hence the Socratic method of extracting this knowledge).

Psychologists of emotion have generally presupposed that the words of eveyday language were well suited to scientific purposes. They further assumed that words such as emotion, anger, fear, and the like are properly defined and referred to things, because nouns were supposed to refer to things. These things were universal and so on. Great but largely forgotten effort went into articulating definitions. These assumptions were accepted without question by most writers. (One important but strangely ignored exception to this generalization was of course William James).

Another important American, Will

(1) El presente trabajo es un comentario de J. A. Russell, autor del artículo objeto de debate en el número anterior de la Revista (7/1). 
importante pero curiosamente ignorada fue naturalmente William James.)

Otro importante americano, Will Rogers, dijo que el problema no es lo que no conoces, sino lo que conoces pero no es así. La reflexión que ha tenido lugar aquí en la $R e$ vista, junto con los comentarios de Clore y Ortony (1991), indican que los psicólogos han comenzado a reconsiderar estos supuestos, a buscar lo que conocen pero no es así. Aunque los autores del debate parten de distintos puntos de vista y llegan a conclusiones diferentes, coinciden en la reconsideración de supuestos fundamentales. Esta reconsideración es lo que es importante y lo que hace de la Psicología de la Emoción actual un campo tan interesante.

El segundo aspecto interesante de esta reconsideración es que las simples afirmaciones sobre el significado y naturaleza de las palabras - como si tales afirmaciones fueran tan obvias que no precisaran más demostración - han sido sustituidas por una amplia búsqueda de sistemas empíricos para decidir cuestiones concretas con respecto a ellas. Así, la reflexión es la base de la investigación. De hecho, la mejor forma de estimular la investigación es a través de reflexiones tales como las que hemos visto en este debate, y cuantas más sean las ideas y perspectivas, mejor. Una vez dicho esto, debo admitir que no estoy de acuerdo con todas las ideas de los comentarios, y aprovecharé esta oportunidad para aportar algunas de mi cosecha.

Ha habido mucha menos controversia sobre la utilidad de la perspectiva en términos de prototipos de la que yo esperaba. Hay una general aceptación de que las personas tienen prototipos para emoción, miedo, rabia, triste$z a$, amor, etc. Dos son las cuestiones que siguen siendo controvertidas: en primer lugar, ¿qué análisis específico del prototipo se aplica mejor a los conceptos de emoción? En esto comparto con Bellelli su escepticismo sobre la existencia de una jerarquía. Clore y Ortony suponen que los scrits de emociones concretas deben ser universales y deben estar presentes en los casos en que se produce esa emoción; yo creo que tales scripts pueden va-
Rogers, said that the problem is not what you don't know, but what you know but ain't so. The discussion that has taken place here in the Revista together with the comments offered by Clore and Ortony (1991) indicate that psychologists have begun to rethink these assumptions, to search for what they know but ain't so. Although the various writers come from quite different points of view and support different conclusions, they now share in the examination of fundamental assumptions. This examination is what is important and what makes the psychology of emotion an exciting field today.

The second interesting feature of these discussions is that simple assertions about the meaning and nature of words - as if the assertion were so obvious that no further backing was necessary - has largely given way to a search for ways to decide specific points in an empirical fashion. Thus, the discussion is a stepping stone to research. Indeed, the very best way to stimulate research is through discussions such as those seen here, and the more ideas and perspectives the better. Having said that, I admit that I don't agree with all the ideas presented, and I shall take this opportunity to give some of my own.

Much less controversy appeared than I had expected on the usefulness of a prototype perspective. That people have prototypes for emotion, fear, anger, sadness, love, and the like is largely accepted. Two issues remain controversial. First, what specific prototype analysis best applies to emotion concepts? Here, I share Bellelli's skepticism about a hierarchy. Clore and Ortony imply that scripts for specific emotions must be universal and must match the actual occurrences of that emotion: I believe that scripts can vary from one person to the next, and that scripts represent not actual frequencies but in some sense ideal cases. Bellelli's approach to individual emotion concepts, such as nostalgia, seems promising in deciding among such different proposals.

Second, what is there in our mental representation of emotions besides prototypes? Are there autobiographical memories? Situational antecedents? 
riar de una a otra persona, y que los scripts no representan frecuencias de hechos sino, de algún modo, casos ideales. La consideración por Bellelli de conceptos individuales de emoción, tales como nostalgia, parece prometedora para decidir entre estas distintas propuestas.

En segundo lugar, ¿qué es lo que hay en nuestras representaciones mentales de las emociones además de los prototipos? ¿Hay memorias autobiográficas? ¿Hay antecedentes situacionales? ¿Redes teoréticas? ¿Elementos clásicos? Naturalmente, tales cuestiones pueden ser resueltas una a una de forma empírica. Mi apuesta es que los recuerdos de episodios concretos, impliquen al yo o a otros, interpretan un papel central (quizás constituyendo incluso un prototipo «a lo Kahneman y Miller»), y que los conceptos de emoción están incluidos en una red teorética. (No pienso en la inclusión teorética como algo controvertido, es la posición ortodoxa en filosofía. Tampoco considero la inclusión teorética como un elemento clásico, tal como hacen Clore y Ortony; un rasgo central de la posición clásica fue que cada concepto es autocontenido, definido únicamente a partir de una lista de características.)

Clore y Ortony, Oatley y Johnson-Laird, y Parrott creen que hay lugar suficiente para los prototipos (para explicar los indicios de estructuras internas) y para los elementos clásicos: Una perspectiva clásica puede tener éxito cuando el tema es, grosso modo, emoción en sí misma o enojo en sí mismo, en lugar de nuestros conceptos cotidianos de emoción o enojo. Las prescripciones sobre cómo caracterizar los acontecimientos emocionales de la forma científicamente más útil no pueden es. tar sometidas a las formas populares de hacerlo. La propuesta, a cargo de Parrott, de una representación prototípica y una representación inconsciente, clásicamente definida, de embarazo se sustenta en la noción de representación. Si su segunda representación, clásica, pudiera ser considerada no como una representación, sino como un mecanismo que determina el embarazo, la propuesta de $\mathrm{Pa}$ rrott de una representación dual sería muy congruente con lo que yo he dicho sobre la perspectiva dual -descriptiva y
Theoretical networks? Classical elements? Of course, these questions must be answered one by one in an empirical manner. My guess is that memories for particular episodes, whether involving the self or others, play a central role (perhaps even constituting the prototype a la Kahneman and Miller), and that concepts of emotion are embedded within a theoretical network. (I don't think of theoretical embeddednes as controversial; it is the orthodox position within philosophy. I also don't think of theoretical embeddedness as a classical element as do Clore and Ortony, one central feature of a classical position was that each concept is self-contained, defined solely in terms of a list of features).

Clore and Ortony, Oatley and JohnsonLaird, and Parrott believe that there is room for both prototypes (to account for manifestations of internal structure) and for classical elements. A classical approach may succeed when the topic is, roughly, emotion per se or anger per se, rather than our everyday concepts of emotion or anger. Prescriptions on how to characterize emotion-like events in the scientifically most useful way cannot be subject to compliance with folk ways. Parrott's proposal for both a prototype representation and a classically defined unconscious representation of embarrassment hinges crucially on the notion of representation. If his second, classical representation can be thought of not as a representation at all, but as the mechanism that determines embarrassment, then Parrott's proposal of a dual representation is largely consistent with what I've said about a dual approach — descriptive and prescriptive - to emotion concepts. The descriptive analysis happens to involve prototypes or scripts (which are not necessarily conscious or explicit), and the presciptive analysis may be classical in the sense of stating necessary and sufficient conditions for a class of events to occur. (My quibble would be over whether that class ought to be labeled embarrassment).

On the question of whether our every'day concepts contain classical elements, I frankly don't know, but I remain a skeptic. As I said, Clore and Ortony's principal can- 
prescriptiva- de los conceptos de emoción. El análisis descriptivo parece implicar prototipos o scripts (que no son necesariamente conscientes o explícitos), y el análisis prescriptivo puede ser clásico en el sentido de establecer las condiciones necesarias y suficientes para que se dé una clase de acontecimientos. (Mi duda sería si tal clase debería ser considerada embarazo.)

Sobre la cuestión de si nuestros conceptos cotidianos contienen elementos clásicos, sinceramente no lo sé, pero sigo siendo escéptico al respecto. Como ya he dicho, el candidato principal de Clore y Ortony, la inclusión teorética, no es un elemento clásico. La noción de representación clásica de $\mathrm{Pa}$ rrott puede ser lo que yo tenía en mente al decir que los acontecimientos emocionales pueden describirse por medio de conceptos definidos clásicamente. Johnson-Laird y Oatley son una ayuda, al señalar que los elementos clásicos conllevan inferencias válidas - por oposición a las inferencias implícitas-. Su observación orienta la reflexión hacia una solución empírica. La cuestión es qué inferencias válidas, si alguna es posible, pueden extraerse de los conceptos de emoción. Carezco de pruebas disponibles sobre la ansiedad de Andrés o el remordimiento de Beatriz, pero la evidencia que he encontrado va en contra de otras inferencias que uno debería ser capaz de extraer, de acuerdo con su teoría: por ejemplo, que si se da asco ello conlleva que se dé una emoción. Esta no parece ser una inferencia válida. En cualquier caso, necesitamos claramente datos sobre el remordimiento y la ansiedad.

Oatley y Johnson-Laird también creen que su análisis clásico se aplica a «todos los lenguajes naturales». Aunque precisamos más y mejores datos sobre esta cuestión (vid. Russell, 1991, para una revisión), la evidencia disponible sugiere que los conceptos de emoción, enojo, tristeza, etc., no son universales.

Dols, Bellelli y Parrott plantean probablemente la cuestión más interesante e importante de todas: ¿Cuál debería ser el papel de nuestros conceptos cotidianos en el pensamiento científico? Esta es una cuestión sobre la que necesitamos reflexionar mucho didate, theoretical embeddedness, is not a classical element. Parrott's notion of a classical representation may be what $I$ had in mind by saying that emotion events per se might be describable by classically defined concepts. Johnson-Laird and Oatley are helpful, by pointing out that classical elements entail valid -as opposed to default - inferences. Their point heads the discussion toward an empirical resolution. The questions is what, if any, valid inferences can be drawn from emotion concepts. I have no evidence on hand about Andrew's anxiety or Beatrice's remorse, but the evidence I have found goes against other inferences one should be able to draw, according to their theory: for example, that the occurrence of disgust implies the occurrence of an emotion. This seems not to be a valid inference. In any case, clearly we need evidence on remorse and anxiety.

Oatley and Johnson-Laird also believe that their classical analysis applies to «all natural languages». Although more and better evidence is needed on this point (see Russell, 1991; for a review), the available evidence suggests that the concepts of emotion, anger, sadness, and so on are not universal.

Dols, Bellelli, and Parrott raise probably the most important and interesting question of all: What should be the role of our everyday concepts in scientific thinking? This is a question on which we need much more discussion. My own opinion is very close to the one Parrott describes for the concept of emotion, although I would apply the same reasoning to anger, fear, embarrassment, and the rest. 
más. Mi opinión está muy próxima a la que Parrott describe para el concepto de emoción, aunque yo aplicaría el mismo razonamiento a enojo, miedo, embarazo, etc.

\section{Referencias}

Clore, G. L. y Ortony, A. (1991). What more is there to emotion concepts than prototypes? Journal of Personality and Social Psychology, 60, 48-50.

Russell, J. A. (1991). Culture and the categorization of emotions. Psychological Bulletin, 110, 426-450. 